\title{
Kontribusi Kreativitas dan Disiplin Belajar Terhadap Hasil Belajar Siswa pada Mata Pelajaran Sasis dan Pemindah Tenaga Kendaraan Ringan Siswa Program Keahlian Teknik Kendaraan Ringan
}

\author{
Yose Fernandes ${ }^{1 *}$, Hasan Maksum ${ }^{2}$, Wawan Purwanto ${ }^{3}$, Eko Indrawan ${ }^{4}$ \\ 1234 Universitas Negeri Padang, Padang, Indonesia \\ *e-mail: yosefernandes401@gmail.com
}

\begin{abstract}
Abstrak
Rendahnya kreativitas dan kedisiplinan siswa dapat berdampak pada kurang efektifnya pelaksanaan pembelajaran, sehingga perlu dianalisis pengaruh kreativitas dan kedisiplinan terhadap hasil belajar siswa. Penelitian ini bertujuan untuk menganalisis kontribusi kreativitas dan disiplin belajar terhadap hasil belajar siswa pada mata pelajaran Sasis Dan Pemindah Tenaga Kendaraan Ringan. Jenis penelitian ini adalah korelasi. Populasi dalam penelitian ini adalah siswa kelas XI dan XII yang berjumlah 55 orang dan diambil 30 orang untuk dijadikan sampel. Metode pengumpulan data didalam penelitian ini dilakukan dengan memberikan instrumen tes berupa angket kreativitas dan kedisiplinan kepada siswa. Teknik analisis data yang digunakan pada penelitian ini menggunakan teknik analisis data statistik kuantitatif. Hasil analisis uji coba penelitian validitas dan reliabelitas mendapatkan 8 butir pernyataan yang tidak valid pada variabel kreativitas belajar (X1) dan pengujian reliabilitas mendapatkan hasil reliability statistics sebesar 0,894. Simpulan penelitian ini adalah instrumen kontribusi kreativitas dan disiplin belajar terhadap hasil belajar siswa pada mata pelajaran Sasis dan Pemindah Tenaga Kendaraan Ringan dinyatakan valid dan reliabel. Implikasi penelitian ini adalah mendapatkan output seberapa besar persentasi kontribusi kreativitas dan disiplin belajar terhadap hasil belajar siswa.
\end{abstract}

Kata kunci: kontribusi kreativitas, disiplin belajar

\begin{abstract}
Low student creativity and discipline can have an impact on the ineffective implementation of learning, so it is necessary to analyze the influence of creativity and discipline on student learning outcomes. This study aims to analyze the contribution of creativity and learning discipline to student learning outcomes in the subject of Chassis and Light Vehicle Power Transfer. This type of research is correlation. The population in this study were students of class XI and XII, amounting to 55 people and 30 people were taken to be the sample. The data collection method in this study was carried out by providing a test instrument in the form of a creativity and discipline questionnaire to students. The data analysis technique used in this study was quantitative statistical data analysis techniques. The results of the analysis of the validity and reliability research trials get 8 invalid statements on the learning creativity variable $(X 1)$ and the reliability test gets the reliability statistics of 0.894 . The conclusion of this research is that the instrument of the contribution of creativity and learning discipline to student learning outcomes in the subject of Chassis and Light Vehicle Power Transfer is declared valid and reliable. The implication of this research is to get the output of how big the percentage contribution of creativity and learning discipline to student learning outcomes.
\end{abstract}

Keywords: contribution of creativity, learning discipline

\footnotetext{
${ }^{*}$ Corresponding author.

Received 30 Januari 2021; Accepted 1 Maret 2021; Available online 8 April 2021 (C) 2021 MI All Rights Reserved
} 


\section{Pendahuluan}

Kurikulum tahun 2013 menuntut kualitas pendidikan yang baik, dilihat dari pelaksanaan pembelajaran yang dilaksanakan di sekolah (Kurniaman \& Noviana, 2017; Malik, 2020; Ponorogo, 2016). Sekolah yang memiliki pelaksanaan pendidikan yang baik dibuktikan dengan pelaksanaan pembelajaran yang efektif, pembelajaran yang efektif merupakan pelaksanaan pembelajaran yang melibatkan siswa, guru, media dan suasana pembelajaran yang saling berinteraksi satu sama lain untuk mencapai tujuan pembelajaran yang diinginkan (Arwanda et al., 2020; Morelent \& Syofiani, 2018; Sugiyanto et al., 2015). Untuk mewujudkannya pelaksanaan pembelajaran yang efektif diperlukan perubahan yang cukup mendasar dalam Sistem Pendidikan Nasional yang dipandang oleh berbagai pihak tidak mampu memberikan bekal serta tidak dapat mempersiapkan peserta didik untuk bersaing dengan bangsa-bangsa lain di dunia. Perubahan mendasar tersebut berkaitan dengan kurikulum yang dengan sendirinya menuntut perubahan pada komponen-komponen pendidikan lain (Indriyani et al., 2019; Nuryana \& Sahrir, 2020; Prasetyo et al., 2016). Pelaksanaan pendidikan dilakukan di sekolah, salah satunya yaitu Sekolah Menengah Kejuruan (SMK).

Berdasarkan hasil observasi di SMK Negeri 2 Payakumbuh merupakan salah satu lembaga pendidikan formal di kota Payakumbuh yang akan menghasilkan lulusan yang berkualitas dan dibutuhkan bekerja baik di dunia usaha atau dunia industri. Namun kenyataannya, terdapat beberapa permasalahan yaitu: (1) seringnya siswa cepat bosan pada saat proses belajar mengajar sehingga kondisi kelas kurang kondusif; (2) siswa menerima apa adanya pelajaran pada saat kegiatan pembelajaran sedang berlangsung; (3) siswa cenderung pasif dan tidak tertarik pada materi yang disampaikan; (4) siswa sering malas dalam belajar di kelas maupun di rumah, sehingga sulitnya siswa menyelesaikan masalah/tugas yang diberikan guru; (5) masih kurangnya pemahaman siswa terhadap tata tertib belajar di kelas. Secara garis besar rendahnya kreativitas dan kedisiplinan siswa dapat berdampak pada kurang efektifnya pelaksanaan pembelajaran, sehingga perlu dianalisis pengaruh kreativitas dan kedisiplinan terhadap hasil belajar siswa.

Kreativitas merupakan hasil dari proses interaksi antara individu dan lingkungan yang tercermin dalam pikiran, perasaan serta sikap atau perilakunya. Seseorang mempengaruhi dan dipengaruhi oleh lingkungan dimana ia berada, dengan demikian baik berubah di dalam individu maupun di dalam lingkungan dapat menunjang atau dapat menghambat upaya kreatif (Hairunisa et al., 2019; Pamungkas et al., 2017; Suryaningsih et al., 2016). Kreativitas dapat diartikan sebagai bakat yang secara potensial dimiliki oleh setiap orang, yang dapat diidentifikasi dan dipupuk melalui pendidikan yang tepat, salah satunya masalah yang kritis adalah bagaimana dapat menemukan potensi kreatif siswa dan bagaimana dapat mengembangkannya melalui pengalaman pendidikan (Oktiani, 2017; Siregar \& Manurung, 2020; Siswanto, 2018). Selain kreativitas permasalahan yang perludiperhatikan yaitu kedisiplinan.

Kedisiplinan siswa pada dasarnya dipengaruhi oleh banyak faktor yang saling terkait, sehingga tidak ada faktor tunggal yang berdiri sendiri. Adapun faktor yang mempengaruhi ketaatan siswa untuk mematuhi tata tertib sekolah terdiri dari faktor dari dalam siswa (internal) ada faktor dari luar diri siswa (eksternal) (Rachmanita et al., 2020; Sari \& Syamsi, 2015; Wariati et al., 2015). Faktor dari dalam diri siswa yaitu motivasi, pemahaman dan kesadaran siswa, sedangkan faktor dari luar yaitu bimbingan guru, bimbingan orang tua, lingkungan masyarakat dan faktor budaya. Konteks ini tentu saja masih banyak lagi masalah-masalah yang dapat ditentukan berkaitan dengan ketaatan siswa dalam mematuhi tata tertib sekolah. Siswa yang memiliki disiplin akan menunjukkan sikap keteraturan dan ketaatannya dalam belajar tanpa ada paksaan dan tekanan dari luar. Disiplin sebagai suatu kondisi yang tercipta dan terbentuk dari serangkaian perilaku yang menunjukkan nilai ketaatan, kepatuhan, kesetiaan, keteraturan atau ketertiban (Ananda, 2018; Fatimah, 2015; Kristin, 2018). Apabila aturan belajar yang telah dibuat 
dilaksanakan oleh siswa secara terus-menerus, maka siswa akan memiliki disiplin belajar yang baik. Belajar dengan disiplin terarah dapat menghindarkan diri dari rasa malas dan menumbuhkan kegairahan siswa dalam belajar.

Penelitian ini didukung dengan penelitian-penelitian sebelumnya yang relevan, seperti: (1) penelitian yang dilakukan oleh Siregar \& Manurung (2020), yang memperoleh hasil penelitian bahwa strategi pembelajaran Blended Learning berpengaruh terhadap kreativitas mahasiswa calon guru di Universitas Negeri Medan; (2) penelitian yang dilakukan oleh Febriana et al., (2020) yang memperoleh hasil penelitian bahwa modul pembelajaran geometri berbasis problem based learning berpengaruh terhadap kreativitas pemecahan masalah siswa; (3) penelitian yang dilakukan oleh Sari \& Syamsi (2015) yang memperoleh hasil penelitian bahwa buku pelajaran tematik-integratif berbasis nilai karakter disiplin dan tanggung jawab siswa dinyatakan layak untuk digunakan. Tujuan penelitian ini adalah menganalisis kontribusi kreativitas dan disiplin belajar terhadap hasil belajar siswa pada mata pelajaran Sasis Dan Pemindah Tenaga Kendaraan Ringan, Program Keahlian Teknik Kendaraan Ringan di SMK Negeri 2 Payakumbuh.

\section{Metode}

Jenis penelitian ini merupakan penelitian kuantitatif bersifat korelasional. Penelitian koreasional bertujuan untuk menemukan hubungan untuk membuat perkiraan yang didasarkan kepada kuat atau lemahnya hubungan antara dua variabel, makin kuat hubungan, maka makin tinggi kontribusinya SUMBER (Anggraini \& Perdana, 2019; Awe \& Benge, 2017; Primayana \& Dewi, 2020). Populasi dalam penelitian ini adalah Siswa Kelas XI dan XII Program Keahlian Teknik Kendaraan Ringan yang terdaftar pada tahun pelajaran 2020/2021 yang berjumlah 55 orang dan diambil 30 orang untuk dijadikan sampel uji coba dengan menggunakan rumus Slovin dengan presisi sebesar $5 \%$.

Metode pengumpulan data didalam penelitian ini dilakukan dengan memberikan instrumen tes berupa angket kreativitas dan kedisiplinan kepada siswa. Penyebaran angket uji coba akan di lakukan pada sampel uji coba yaitu Kelas XI TKR yang berjumlah 30 orang siswa. Angket uji coba memiliki butiran pernyataan yang telah disusun berdasarkan observasi keadaan di sekolah serta diperkuat dengan beberapa penelitian yang relevan. Jumlah pernyataan angket uji coba tersebar sebanyak 49 butir pernyataan yang dibagi menjadi 25 butir pernyataan variabel kreativitas belajar dan 24 butir pernyataan variabel disiplin belajar.

Teknik analisis data yang digunakan pada penelitian ini menggunakan teknik analisis data statistik kuantitatif. Dalam penulisan artikel ini di spesifikkan pada uji coba angket penelitian, dengan menjabarkan serta mendeskripskan hasil butiran angket berupa tabulasi, yang nantinya di lakukan pengujian validasi dan reliabelitas.

\section{Hasil dan Pembahasan}

Berdasarkan hasil uji coba penelitian Penyebaran angket uji coba akan di lakukan pada sampel uji coba yaitu Kelas XI TKR yang berjumlah 30 orang siswa. Angket uji coba memiliki butiran pernyataan yang telah disusun berdasarkan observasi keadaan di sekolah serta diperkuat dengan beberapa penelitian yang relevan. Jumlah pernyataan angket uji coba tersebar sebanyak 49 butir pernyataan yang dibagi menjadi 25 butir pernyataan variabel kreativitas belajar dan 24 butir pernyataan variabel disiplin belajar. Angket uji coba di sebar satu bulan sebelum Ujian Akhir Semester Ganjil 2020-2021. Hasil analisis uji coba penelitian validitas dan reliabelitas mendapatkan 8 butir pernyataan yang tidak valid pada variabel kreativitas belajar (X1) serta 5 butir pernyataan yang tidak valid pada variabel disiplin belajar siswa. Pengujian reliabilitas dilakukan untuk mengetahui konsistensi jawaban responden terhadap suatu pernyataan dengan SPSS 
versi 20 , dengan mendapatkan hasil reliability statistics sebesar 0,894 , sebagai tingkat reliabilitas skala sangat tinggi.

Kreativitas merupakan hasil dari proses interaksi antara individu dan lingkungan yang tercermin dalam pikiran, perasaan serta sikap atau perilakunya. Seseorang mempengaruhi dan dipengaruhi oleh lingkungan dimana ia berada, dengan demikian baik berubah di dalam individu maupun di dalam lingkungan dapat menunjang atau dapat menghambat upaya kreatif (Hairunisa et al., 2019; Pamungkas et al., 2017; Suryaningsih et al., 2016). Kreativitas dapat diartikan sebagai bakat yang secara potensial dimiliki oleh setiap orang, yang dapat diidentifikasi dan dipupuk melalui pendidikan yang tepat, salah satunya masalah yang kritis adalah bagaimana dapat menemukan potensi kreatif siswa dan bagaimana dapat mengembangkannya melalui pengalaman pendidikan (Oktiani, 2017; Siregar \& Manurung, 2020; Siswanto, 2018). Selain kreativitas permasalahan yang perlu diperhatikan yaitu kedisiplinan.

Kedisiplinan siswa pada dasarnya dipengaruhi oleh banyak faktor yang saling terkait, sehingga tidak ada faktor tunggal yang berdiri sendiri. Adapun faktor yang mempengaruhi ketaatan siswa untuk mematuhi tata tertib sekolah terdiri dari faktor dari dalam siswa (internal) ada faktor dari luar diri siswa (eksternal) (Rachmanita et al., 2020; Sari \& Syamsi, 2015; Wariati et al., 2015). Faktor dari dalam diri siswa yaitu motivasi, pemahaman dan kesadaran siswa, sedangkan faktor dari luar yaitu bimbingan guru, bimbingan orang tua, lingkungan masyarakat dan faktor budaya. Konteks ini tentu saja masih banyak lagi masalah-masalah yang dapat ditentukan berkaitan dengan ketaatan siswa dalam mematuhi tata tertib sekolah.

Siswa yang memiliki disiplin akan menunjukkan sikap keteraturan dan ketaatannya dalam belajar tanpa ada paksaan dan tekanan dari luar. (Murniyetti et al., 2016; Saputro \& Soeharto, 2015; Widiatmaka, 2016) menjelaskan bahwa disiplin sebagai suatu kondisi yang tercipta dan terbentuk dari serangkaian perilaku yang menunjukkan nilai ketaatan, kepatuhan, kesetiaan, keteraturan atau ketertiban. Apabila aturan belajar yang telah dibuat dilaksanakan oleh siswa secara terus-menerus, maka siswa akan memiliki disiplin belajar yang baik. Belajar dengan disiplin terarah dapat menghindarkan diri dari rasa malas dan menumbuhkan kegairahan siswa dalam belajar.

Penelitian ini didukung dengan penelitian-penelitian sebelumnya yang relevan, seperti: (1) penelitian yang dilakukan oleh Siregar \& Manurung (2020) yang memperoleh hasil penelitian bahwa strategi pembelajaran Blended Learning berpengaruh terhadap kreativitas mahasiswa calon guru di Universitas Negeri Medan; (2) penelitian yang dilakukan oleh Febriana et al., (2020), yang memperoleh hasil penelitian bahwa modul pembelajaran geometri berbasis problem based learning berpengaruh terhadap kreativitas pemecahan masalah siswa; (3) penelitian yang dilakukan oleh Sari \& Syamsi (2015), yang memperoleh hasil penelitian bahwa buku pelajaran tematik-integratif berbasis nilai karakter disiplin dan tanggung jawab siswa dinyatakan layak untuk digunakan.

Implikasi penelitian ini adalah mendapatkan output seberapa besar persentasi kontribusi kreativitas dan disiplin belajar terhadap hasil belajar siswa pada mata pelajaran Sasis dan Pemindah Tenaga Kendaraan Ringan, Jurusan Otomotif Program Keahlian Teknik Kendaraan Ringan.

\section{Simpulan}

Berdasarkan hasil uji coba angket penelitian yang telah diuraikan maka dapat disimpulkan bahwa instrumen kontribusi kreativitas dan disiplin belajar terhadap hasil belajar siswa pada mata pelajaran sasis dan pemindah tenaga kendaraan ringan siswa program keahlian teknik kendaraan ringan dinyatakan valid dan reliabel. Implikasi penelitian ini adalah mendapatkan output seberapa besar persentasi kontribusi kreativitas dan disiplin belajar terhadap hasil belajar siswa pada mata pelajaran Sasis dan Pemindah 
Tenaga Kendaraan Ringan, Jurusan Otomotif Program Keahlian Teknik Kendaraan Ringanr.

\section{Daftar Pustaka}

Anggraini, L., \& Perdana, R. (2019). Hubungan Sikap dan Percaya Diri Siswa Pada Mata Pelajaran IPA di Sekolah Menengah Pertama. Spektra: Jurnal Kajian Pendidikan Sains, 5(2), 188-199. https://doi.org/10.32699/spektra.v5i2.103

Arwanda, P., Irianto, S., \& Andriani, A. (2020). Pengembangan Media Pembelajaran Articulate Storyline Kurikulum 2013 Berbasis Kompetensi Peserta Didik Abad 21 Tema 7 KelaS IV Sekolah Dasar. Al-Madrasah: Jurnal Pendidikan Madrasah Ibtidaiyah. https://doi.org/10.35931/am.v4i2.331

Awe, E. Y., \& Benge, K. (2017). Hubungan Antara Minat Dan Motivasi Belajar Dengan Hasil Belajar Ipa Pada Siswa SD. Journal of Education Technology, 1(4), 231. https://doi.org/10.23887/jet.v1i4.12859

Febriana, R., Yusri, R., \& Delyana, H. (2020). Modul Geometri Ruang Berbasis Problem Based Learning Terhadap Kreativitas Pemecahan Masalah. Aksioma: Jurnal $\begin{array}{llll}\text { Program Studi Pendidikan } & \text { Matematika, }\end{array}$ https://doi.org/10.24127/ajpm.v9i1.2591

Hairunisa, Arif Rahman Hakim, \& Nurjumiati. (2019). Studi Pengaruh Model Pembelajaran Berbasis Proyek (Project Based Learning) Terhadap Kreativitas Mahasiswa Program Studi PGSD Pada Mata Kuliah Konsep Dasar IPA. Jurnal Pendidikan Mipa, 9(2), 93-96. https://doi.org/10.37630/jpm.v9i2.190

Indriyani, V., Zaim, M., Atmazaki, A., \& Ramadhan, S. (2019). Literasi Baca Tulis Dan Inovasi Kurikulum Bahasa. KEMBARA: Jurnal Keilmuan Bahasa, Sastra, Dan Pengajarannya, 5(1), 108. https://doi.org/10.22219/kembara.vol5.no1.108-118

Kurniaman, O., \& Noviana, E. (2017). Penerapan Kurikulum 2013 Dalam Meningkatkan Keterampilan, Sikap, Dan Pengetahuan. Primary: Jurnal Pendidikan Guru Sekolah Dasar, 6(2), 389. https://doi.org/10.33578/jpfkip.v6i2.4520

Malik, M. S. (2020). ANALISIS HOTS, 4C, Literasi, Dan Pendidikan Karakter Dalam Seni Budaya Dan Prakarya MI/SD Kurikulum 2013. Elementary Islamic Teacher Journal, 8(1), 59-82. https://doi.org/10.21043/elementary.v8i1.6727

Morelent, Y., \& Syofiani. (2018). Pengaruh Penerapan Kurikulum 2013 Terhadap Pembentukan Karakter Siswa Sekolah Dasar Negeri 05 Percobaan Pintu Kabun Bukittinggi. Jurnal Penelitian Bahasa Dan Sastra Indonesia, 1(2), 141-152. https://doi.org/10.22202/jg.2015.v1i2.1234

Murniyetti, M., Engkizar, E., \& Anwar, F. (2016). Pola Pelaksanaan Pendidikan Karakter Terhadap Siswa Sekolah Dasar. Jurnal Pendidikan Karakter, 6(2), 156-166. https://doi.org/10.21831/jpk.v6i2.12045

Nuryana, N., \& Sahrir, D. C. (2020). Pelatihan Kurikulum 2013 Edisi Revisi 2018 bagi Guru di Yayasan Pendidikan Islam Al-Maunah. Jurnal Pengabdian Pada Masyarakat, 5(1), 1-10. https://doi.org/10.30653/002.202051.259

Oktiani, I. (2017). Kreativitas Guru dalam Meningkatkan Motivasi Belajar Peserta Didik. Jurnal Kependidikan, 5(2). https://doi.org/10.24090/jk.v5i2.1939

Pamungkas, A., Subali, B., \& Lunuwih, S. (2017). Implementasi Model Pembelajaran IPA Berbasis Kearifan Lokal untuk Meningkatkan Kreativitas dan Hasil Belajar Siswa. Jurnal Inovasi Pendidikan IPA, 3(2), 118-127. https://doi.org/10.21831/jipi.v3i2.14562 
Ponorogo, I. (2016). Implementasi Penanaman Karakter Melalui Matematika Pada Kurikulum 2013. Ibriez: Jurnal Kependidikan Dasar Islam Berbasis Sains, 1(1). https://doi.org/10.21154/ibriez.v1i1.4

Prasetyo, A., Hartini, T., Damayani, A., Mushafanah, Q., \& Zahraini, D. A. (2016). IbM Himpaudi Kecamatan Kaliwungu Kendal Dalam Rangka Penyusunan Perangkat Pembelajaran Kurikulum 2013. E-Dimas: Jurnal Pengabdian Kepada Masyarakat, 7(2), 1 - 8. https://doi.org/10.26877/e-dimas.v7i2.1128

Primayana, K. H., \& Dewi, P. Y. A. (2020). Hubungan Pola Asuh Demokratis dan Intensitas Penggunaan Gawai pada Anak Usia Dini. Jurnal Obsesi: Jurnal Pendidikan Anak Usia Dini, 5(1), 710-718. https://doi.org/10.31004/obsesi.v5i1.697

Rachmanita, L. D., Hidayat, O. S., \& Sudrajat, A. (2020). Peningkatan Kedisiplinan Dan Prestasi Belajar Melalui Model Value Clarification Technique Di Sekolah Dasar. 3(4), 994-1004. https://doi.org/10.31004/basicedu.v3i4.225

Saputro, H. B., \& Soeharto. (2015). Pengembangan Media Komik Berbasis Pendidikan Karakter Pada Pembelajaran Tematik-Integratif Kelas IV SD. Jurnal Prima Edukasi, 3(1), 61 - 72. https://doi.org/10.21831/jpe.v3i1.4065

Sari, I. P., \& Syamsi, K. (2015). Pengembangan Buku Pelajaran Tematik-Integratif Berbasis Nilai Karakter Disiplin Dan Tanggung Jawab Di Sekolah Dasar. Jurnal Prima Edukasi, 3(1), 73-83. https://doi.org/10.21831/jpe.v3i1.4070

Siregar, N., \& Manurung, S. L. (2020). Pengaruh Blended Learning terhadap Kreativitas Mahasiswa Calon Guru di Universitas Negeri Medan. Edumatika: Jurnal Riset Pendidikan Matematika, 3(1), 44. https://doi.org/10.32939/ejrpm.v3i1.485

Siswanto, J. (2018). Keefektifan Pembelajaran Fisika dengan Pendekatan STEM untuk Meningkatkan Kreativitas Mahasiswa. Jurnal Penelitian Pembelajaran Fisika, 9(2). https://doi.org/10.26877/ jp2f.vv9i2.3183

Sugiyanto, S., Kartowagiran, B., \& Jailani, J. (2015). Pengembangan Model Evaluasi Proses Pembelajaran Matematika Di SMP Berdasarkan Kurikulum 2013. Jurnal Penelitian Dan Evaluasi Pendidikan, 19(1), 82-95. https://doi.org/10.21831/pep.v19i1.4558

Suryaningsih, N. M. A., Cahaya, I. M. E., \& Poerwati, C. E. (2016). Implementasi Pembelajaran Inkuiri Terbimbing Berbasis Permainan Dalam Meningkatkan Kreativitas Anak Usia Dini. JPI (Jurnal Pendidikan Indonesia, 5(2), 512-220. https://doi.org/10.23887/jpi-undiksha.v5i2.8559

Wariati, N., Dahniar, \& Sugiati, T. (2015). Pengaruh Disiplin Kerja dan Pengalaman Kerja Terhadap Kinerja Pegawai Dinas Pendapatan Pengelolaan Keuangan dan Aset Kabupaten Barito Timur. Jurnal Wawasan Manajemen, 3(3), 217-228. https://doi.org/http://dx.doi.org/10.20527/jwm.v3i3.3

Widiatmaka, P. (2016). Kendala Pendidikan Kewarganegaraan dalam membangun karakter peserta didik di dalam proses pembelajaran. Jurnal Civics: Media Kajian Kewarganegaraan, 13(2), 188-198. https://doi.org/10.21831/civics.v13i2.12743 